\title{
Three-Phased Sustainable Design and Development Project at Université de Moncton.
}

\author{
Ronald Babin \\ Département de sociologie \\ Université de Moncton \\ babinr@umoncton.ca
}

\begin{abstract}
Since 2000, Université de Moncton is the site of a three-phased academic environmental research, development, creation (RDC) initiative: (1) installation in 2000 on the University's main campus of a 4 hectares Millennium Ecological park; (2) integration since 2002 of permanent and growing nature art installations towards an open air nature art museum in the park; and (3) development project of an Atlantic Canada Housing and Environmental Technology Centre. From a societal modernization theoretical approach, we will examine the direction and scope of this partnership based initiative which seeks to develop, demonstrate and communicate sustainable practices that contribute to social change regarding environmental and climate change issues.
\end{abstract}

\section{Introduction}

Since the year 2000, Université de Moncton has been actively involved in a three-phased project (http://www.umoncton.ca/babinr/centre/) developed early on as a community and institutional education program aimed at raising and strengthening environmental awareness activities of professors, students, surrounding community, as well of artists, businesses and policy makers. In addition, the installation of an Ecological park (phase 1) followed by the introduction of activities for integrating nature art (phase 2) and the ongoing development of a Housing
Centre project (phase 3) in the Ecopark are also aimed at integrating Université de Moncton in the overall development of sustainable green campuses in NB, Canada and elsewhere whereby universities are increasingly becoming involved in developing and demonstrating various initiatives favouring sustainability.

Such environmental activities are being developed in a context of a significant societal debate concerning the nature and scope of sustainable development that began with the publication in 1987 of the well known Brundtland report entitled Our Common Future and which continued and deepened during the Rio de Janeiro Earth Summit of 1992 and the follow up Johannesburg Sustainable Development Summit of 2002. At issue is a fundamental conflict and persistent large gap between neoliberal objectives of maintaining the existing rhythm of capitalist development while minimizing negative effects on the natural environment and its resources on the one hand and on the other environmentalist objectives of institutional and societal reorientations capable of producing positive effects on ecosystem integrity and the strengthening of democracy. This deep divide remains largely present in the formulation and make-up of two modernization projects that are simultaneously antagonist and interdependent, and concern the ecological modernization of the economy and the societal modernization of the grammar of life. Tables 1 and 2 give a succinct overview of this societal conflict with at stake forms of management of social change.

In Acadia as elsewhere, there are various environmental initiatives inspired by one or other approaches and an analysis of differences is not the 
object here as done previously (Babin 2003, 2004).

Table 1. Ecological modernization of the economy

\begin{tabular}{|c|}
\hline Instituted techno-scientific rationality \\
\hline Instrumental control logic \\
\hline Direct power and laisser faire mentality \\
\hline Ordered management of ecosystems \\
\hline Optimization and performance \\
\hline $\begin{array}{c}\text { Reproducing the economy: individuality, } \\
\text { profitability, competitiveness and financial } \\
\text { equilibrium }\end{array}$ \\
\hline Unlimited technological solutions \\
\hline $\begin{array}{c}\text { Domination and mastering nature } \\
\text { the environment with little care for cultures and } \\
\text { democracy }\end{array}$ \\
\hline $\begin{array}{c}\text { Key role for leaders and expertise: socio- } \\
\text { political planning, political apathy and social } \\
\text { exclusion. }\end{array}$ \\
\hline $\begin{array}{c}\text { Targeting ruling classes and resource } \\
\text { allocations }\end{array}$ \\
\hline Human person: object of chance; adapting \\
communities to change \\
\hline Educate and passively inform \\
Sustained development \\
\hline Culture of objects and means \\
\hline
\end{tabular}

Table 2. Societal modernization of living conditions

\begin{tabular}{|c|}
\hline Instituting communicational rationality \\
\hline Relational logic of interdependence \\
\hline Relational power and social involvement ethic \\
\hline Dynamic management of human activities \\
\hline $\begin{array}{c}\text { Efficiencies and development } \\
\text { seproducing society: protecting the commons, } \\
\text { solidarity, participation and ecological } \\
\text { equilibrium }\end{array}$ \\
\hline Knowing and understanding natural limits \\
\hline Mastering science and appropriate technologies \\
\hline $\begin{array}{c}\text { Human and social knowledge as well as a break } \\
\text { towards new learning processes and actions on } \\
\text { society }\end{array}$ \\
\hline $\begin{array}{c}\text { Key role for citizens and civil society: social } \\
\text { politization, remobilizing and rehabilitating } \\
\text { democracy }\end{array}$ \\
\hline $\begin{array}{c}\text { Objective of institutional cultural adjustments } \\
\text { and innovations through communities }\end{array}$ \\
\hline $\begin{array}{c}\text { Human person: agent of change; engaging } \\
\text { communities in fostering change }\end{array}$ \\
\hline Taking responsibility and actively involving \\
\hline Developing sustainability and viability \\
\hline Culture of persons and objectives \\
\hline
\end{tabular}

Rather from a societal modernization theoretical approach, this paper will examine the question of direction and scope of this three-phased partnership based initiative which seeks to develop, demonstrate and communicate sustainable practices that contribute to social change in regards to environmental and climate change issues. In 2004, an important commemorative year of the $400^{\text {th }}$ anniversary of modern Acadia, this forward looking approach brings together a variety of academic disciplines as well as partners from various artistic, governmental, non governmental and private sector organizations that are brought into play as actors in human and natural settings where new questions are asked and new initiatives find their social relevance.

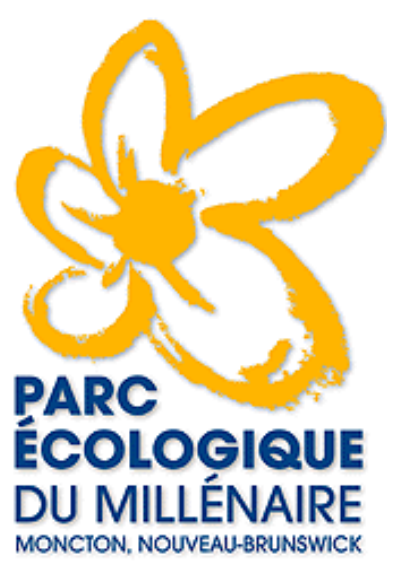

Figure 1. Park logo

\section{Ecological park}

The development of the Millennium ecological park (34 hectares) is of course linked to the general vision of greening university campuses for environmental education and demonstration purposes. But in terms of conceptualization and content, it offers much more than a mere walk in the park as the project seeks also to input into a larger debate regarding the need to redefine the existing notion of nature parks that for the time being is far to often associated with directives and constraints. What is now required to foster new learning processes is the promotion of multi-use territories that encourage integration of populations into activities that promote resource protection and better understanding of ecological functions of nature and their restoration if needed. As such, the main objective in developing this Eco park has been to work in partnership with the community to demonstrate a new generation of nature parks in an urban setting that highlight the need to restoring various ecological functions of nature such as natural drainage systems, soil conditions and native plant communities, re- 
establishing storm water control and wildlife corridors where possible, and promoting passive energy conservation strategies that respond to local climate, etc. In addition, as the park is to be linked to the tricommunities (Moncton, Dieppe, Riverview) linear park that is also integrated into the Trans-Canada trail system, the park offers a resting area where people can contemplate this particular nature setting in the middle of a city and on a university campus. Moreover as the park has been conceived as an important vehicle for awakening and promoting environmental awareness and in view the multi-use integration of nature art and a proposed housing centre, it is also possible to envisage this site becoming an important learning milieu as to the possibilities that exist and that should be promoted in order to foster sustainable community development practices.

The initial development of the ecological park has been brought about by an association of 17 community, private and public stakeholders [1] that accepted often enthusiastically to participate through financial and in kind contributions of $600000 \$$ to launch the project. Initial development work consisted mainly of eliminating mowing of this terrain, a very large green lawn area containing 100 trees, in order to allow natural succession that was aided by the planting of selected areas with 650 native trees, shrubs and groundcovers. A constructed wetland was achieved by the restoration of an abandoned eutrophied pond and by the integration of swales and filter strips. In addition, in order to encourage community access, gravel pathways were incorporated in the least intrusive manner possible as well as the construction of a gazebo in lieu for a public meeting place at the center of the park.

[1] Acadia Crushed Stone, Association acadiennes des artistes professionnel.le.s du NB (AAAPNB), Basic Design Associates, Branch Graphic Design, Canadian Millennium Partnership Program, City of Moncton ,Eastern Fence, Enseignes Hansen Signs, Fondation Médias Verts, Goguen Lumber, Katimavik, MacArthur's Nurseries, Modern Construction (Moncton Crushed Stone), Nova Construction, Oh! Communications, Price Contractors, Université de Moncton.

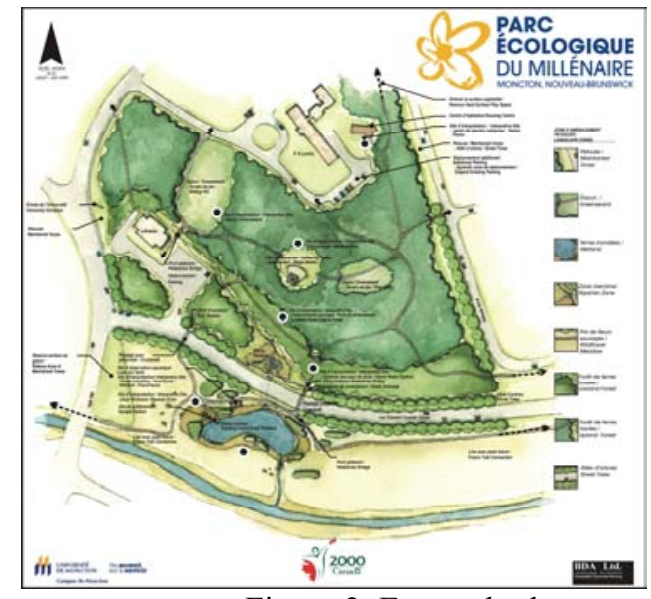

Figure 2. Eco park plan

\section{Nature Art}

From the onset, an artistic component was seen as an essential element in the Ecopark. This led to an active collaboration with l'Association des artistes acadiens professionnel.le.s du Nouveau-Brunswick (AAAPNB), the Visual Arts department and the University's art gallery in order to guide the integration of growing and permanent nature art work installations in the park. As a starting point, an invitation was addressed to NilsUdo, a world renowned artist and pioneer of nature art, in order to create the park's first nature art installation. During his first visit in the autumn of 2001 in order to scope the site, the artist produced conceptual sketches (figures 3 and 4) of his proposed installation that he entitled "Entrée" (Entrance) as a metaphor of the need for societies to enter into a new relationship with nature in order to correctly address our ongoing ecological crisis. These sketches as well as the artist's notoriety were key to securing financial commitments near the $50000 \$$ required in order to complete the project a year later.

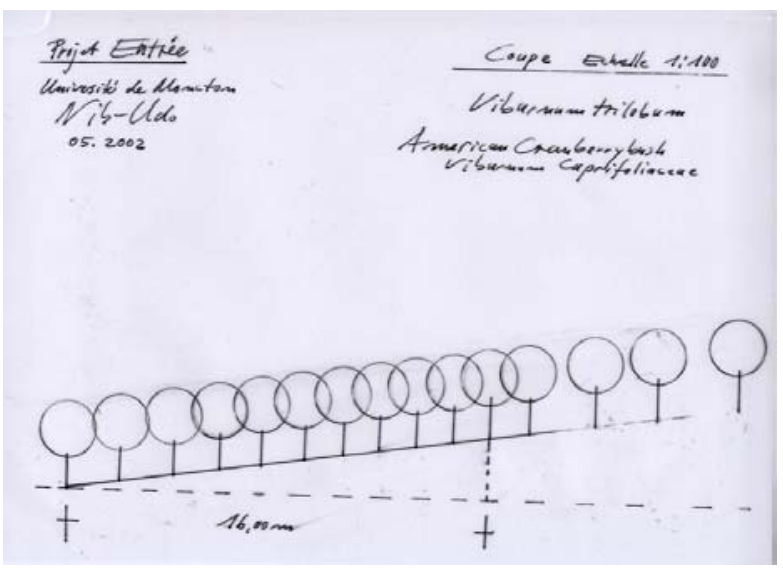

Figure 3. Entrée side view 


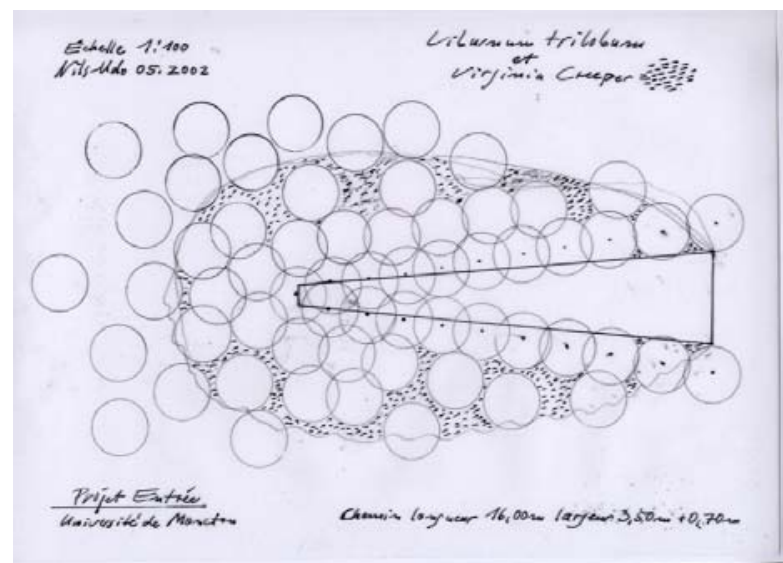

Figure 4. Entrée from above

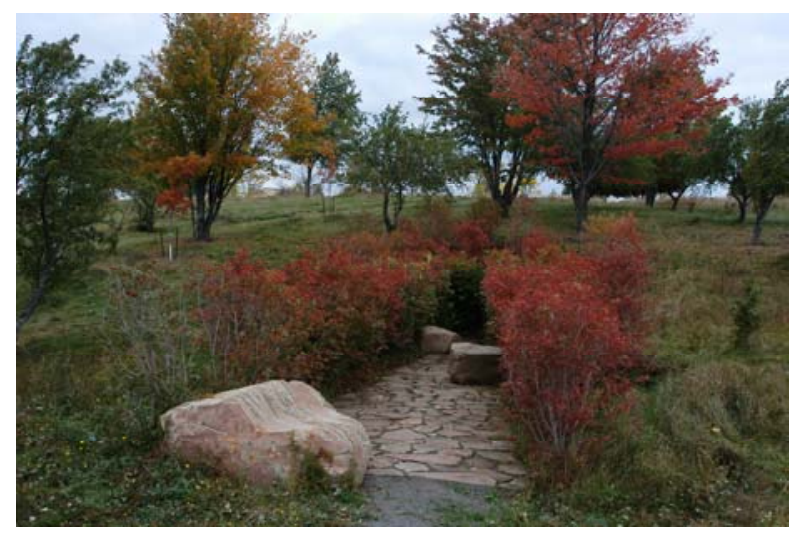

Figure 5. Entrée October 2003

Following this first initiative, the longer term objective is to reedit such an undertaking every two years with other renowned artists in such a manner as to constitute over time an open sky nature art museum. The next step is projected in the context of an upcoming nature art symposium in October 2004 entitled "Art nature en Acadie 2004". This in effect constitutes an unedited artistic, aesthetic and social concept in Acadia and New-Brunswick, and the choice of launching this project with a respected international artist speaks volume of the willingness to distinguish and position this new artistic initiative whose scope and range holds considerable interest in view of its innovative character.

In addition, to promoting dialogue and cultural exchange via an international artist, this creative approach not only allies art and nature but academically and socially it associates the departments of sociology and visual arts of the university[2] as well

[2] This project is being developed in a collaborative inter-disciplinary manner by: Ronald Babin, professor of sociology and coordinator of Ecological park as diverse stakeholders from public and private sectors. This new initiative has also been developed with the active involvement of l'Association acadienne des artistes professionnel.le.s du Nouveau-Brunswick (AAAPNB) which regroups 230 artistes members in six artistic disciplines [3] who embraces this project as an excellent occasion to help create an new audience for the arts as well as a means to favour the development of a new nature art approach in Acadia and New-Brunswick. Support from the federal government (Canada Council for the Arts) and by the provincial government (New-Brunswick Arts Board) has also been an important factor in getting this partnership based dynamics off the ground.

Success in mobilizing persons and resources is in itself very significant and corresponds to a new expression of the social functions of artistic creativity in contemporary societies. By bringing together various social categories in creative processes of producing nature artwork expressing sentiments of nature, nature art seems to favour greater efficiency in expressing ideas and working together, two important factors favouring in return greater interest and participation by concerned individuals in questions of interest to society. This is quite significant and should by no means be dismissed but rather encouraged in these times of growing democratic deficit.

However, it also should be understood that from an instrumental point of view and for various reasons linked to the digital economy, to neoliberalism and to globalization, it appears that non material investments are increasingly becoming a key factor in the conduct of business in the world. In fact, national, provincial and local governments increasingly limited in their capacities to effectively regulate economic cycles through traditional macro-economic instruments are now turning towards increasing the attractiveness of their productive milieus all the while enhancing and promoting overall national, regional and local socioeconomic conditions. Art plays an increasingly important role as can be seen by the use by civic and political leaders of the Bohemian index [4] that

projects; André Lapointe, professor of sculpture and responsible for the artistic component of the park; Luc Charrette, director of the University art gallery; and Carmen Gibbs, general director of 1'Association acadienne des artistes professionnel.le.s du NouveauBrunswick (AAAPNB).

[3] Visual arts, literature, dance, theatre, video-cinema and music.

[4] This index has been developed following observations and research conducted by Richard 
measures the relationship between the density of a bohemian population of artist and their creative activities on the one hand and on the other the presence of dynamic and innovative technology companies that are seen as the principal motor for growth and economic vitality of city-regions. What this suggests is that knowledge, creativity and ideas have replaced energy, property and resources as the principle source for creating value and growth but also that the intrinsic capacities of regions to attract modern competitive technology based industries is in direct correlation with their capacities to attract and nurture a varied and culturally diversified bohemian creative artistic community composed of artists, writers, composers, etc. On the whole, this also signals movement away from a company centred economy to a people driven economy shaped by creative and talented people for whom the quality of the social environment where they live is of considerable importance.

Cities that wish to prosper should be attentive to the needs of this new "creative class" that Richard Florida estimates represents more than $35 \%$ of the active population in the leading centers of this "new class geography"[5]. For this to happen, cities must to what is required to develop and nurture a significant cultural scene by offering fiscal advantages to bohemians and by opening up to ethnic and gay communities. This is without a doubt a significant broadening of the concept of culture seen here in a quality of life strategy and also a strategic territorial development strategy in view of contemporary challenges linked to increasing global competition and influx of migrant populations. Yet, this particular approach is also characterized by a kind of fusion or confusion of the arts, of concepts and of powers that authorize a general instrumentation of important elements of culture whereby artistic values are identified to merchant values. From this flows a loss of meaning or more aptly a merchant appropriation of artistic meaning. As such, it thus appears that this significant overture towards culture is in fact limited by an attitude of economic glorification that occults important socio-political and education dimensions of culture, all the while neglecting to highlight the significance of various forms of development and organization of artistic productions with more profound cooperative, democratic, and ecological values in mind.

It is then quite important to understand more

Florida, regional economic professor at Carnegie Mellon University in Pittsburgh, Pennsylvania.

[5] FLORIDA, Richard. "The Rise of the Creative Class », The Washington Monthly, Online, May 2002. profoundly the question of artistic meanings and sensitivities that nature art conveys in order to better appreciate how this contemporary art form there is a genuine refusal to resign oneself to an instrumental loss of meaning of nature artworks coupled with a firm determination to control meaning and diffuse it widely often through photography, catalogues, books and digital communication. In fact, important fundamental questions are to be addressed, particularly with permanent and growing nature art because is there not up front as a creative criteria the central importance of working on meaning in a continuous, engaged and evolving manner rather than agreeing with the more static merchant view of the arts? And more generally, is it not true that the creative act in nature art seeks consciously to maintain control over process and scope all the while trying to ensure wide scale memory and diffusion through photography published in catalogues or books in order to foster public communication and also exchange of meaning and ideas, all of which is very much in line with contemporary central challenges and debates concerning environmental and developmental issues?

\section{Housing Centre project}

Housing is a reflection of society, economy and environment. People require shelter. The housing industry provides employment and generates wealth for many communities. Housing also impacts on the environment over the short and long terms. While some innovative eco-conscious design practices may be used in expensive model homes, not much has been done in the way of green buildings for low and moderately priced housing. Sustainable and affordable housing represents challenges for builders, industry, government and the public. Research, education and experimentation into the use of innovative materials and building techniques are required. Demonstrations of healthier and more environmentally conscious consumer practices are also needed to generate more awareness of our impact on the environment. Communicating the benefits of environmental and healthy housing decisions and practices must also form an integral part of any initiative that aims to further the concept of healthy housing. 


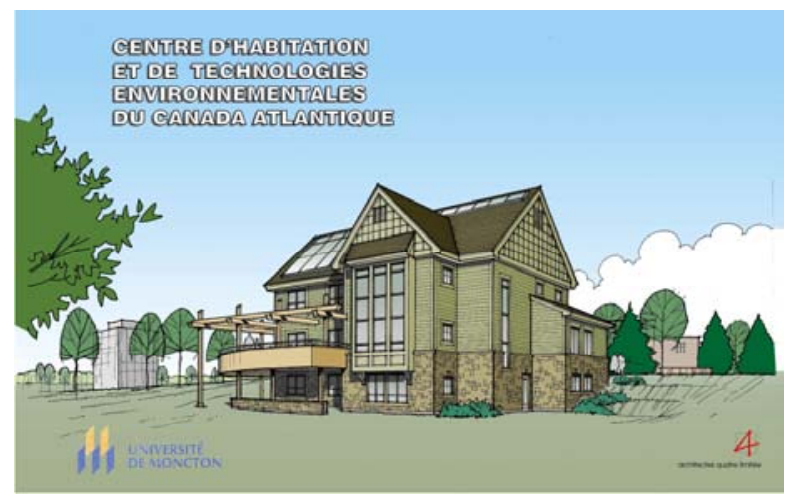

Figure 6. Housing centre south face

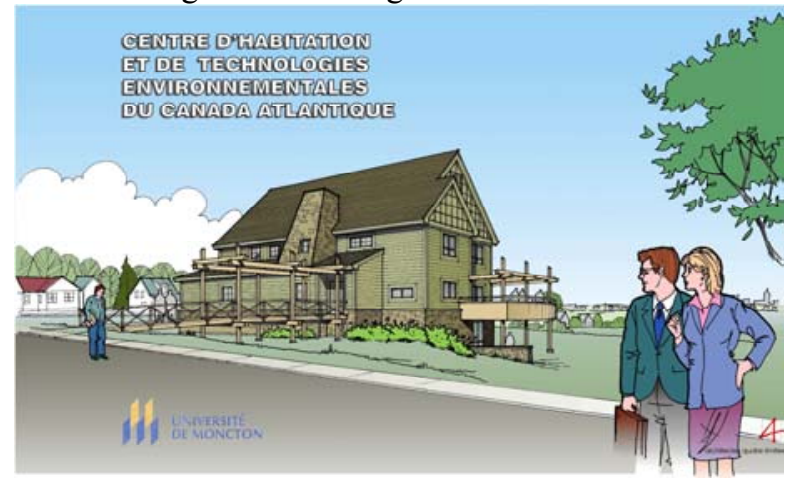

Figure 7. Housing centre north face

According to Statistic Canada, housing consumes 20\% of the total energy used in Canada. Of this percentage, $67 \%$ of energy is devoted to heating and airconditioning, $18 \%$ for lighting and appliances, and $15 \%$ for water heating. Today, technologies exist to help reduce the total energy consumed by Canadian households and businesses. Many of these can easily be applied when decisions are made to build or renovate residential, commercial and industrial buildings. Other innovations are more complex and require further development before they can be implemented on a much broader scale. The Housing Centre project of Université de Moncton aims to engage the community, industry, government and nongovernment organizations, as well as academia in a collective effort to raise environmental awareness around these issues and in regards to Canada's commitments within the Kyoto Protocol on Climate Change.

The Project's purpose it to educate and to advance the application of environmental housing practices, technologies and know-how and to demonstrate ways in which individuals may change their consumption patterns. The Housing Centre will help channel efforts in testing and demonstrating new environmental building technologies. The Centre will strive to bring about change on three levels: raising awareness, educating and fostering technology and innovation.

\section{Awareness}

People and businesses can play a vital role by making conscious decisions in favour of non-toxic, renewable or recyclable materials that are not produced from sensitive ecological environments. Raising awareness in support of environmental technologies to create healthier living and working environments requires communicating relevant information and demonstrating their application to the community at large. The Housing Centre will raise awareness by showcasing environmental innovation and energy-efficient construction techniques and by communicating the benefits of healthy housing. Proposed program highlights include: green campus initiative, materials and construction demonstration program and resource centre, Web-based information clearinghouse, volunteers training program, and consumer communications program.

\section{Learning and Teaching}

Adopting environmental technologies and using innovative construction techniques requires learning how to apply new concepts and products. The Housing Centre will foster learning in the use and application of advancements in non-toxic, renewable or recyclable materials. A multi-disciplinary approach to experimenting and researching new products and building procedures will ensure that knowledge of environmental technologies is transferred between academics, students, practitioners, industry and the public. Opportunities to learn from the concepts and procedures used in building more efficient housing are also part of the process aimed at increasing healthy housing know-how. Other training environments include a healthy home-building school, technical seminars, and conservation workshops.

\section{Technology}

Healthy housing requires a number of important ingredients. Most importantly, industry must play a significant role in creating the healthy housing concept promoting sustainable building technologies. Initiatives will include product demonstrations, applied research and knowledge transfer to global markets.

\section{Conclusion}

As it should now be quite evident, the inspiration leading to innovation in these three distinct but integrated projects is not while present mainly technical in nature but very much more social in essence in that they together seek to communicate a simple, logical message but with important 
implications : resolving the escalating ecological crisis will not come about by mainly modernizing management of ecosystems and technological fixes but rather by inviting modernization of societies as a whole in such a manner as to change cognition, increase commitments, take responsibility, and strengthen involvements in processes leading to significant societal changes in regards to our natural environment and to how we organize ourselves. The environment is not the problem; rather it is our various societies relationships to nature, and also our own relationships amongst ourselves. Thus, it is from within societies that we have to foster the reflexive learning processes leading to new lifestyle choices, to more appropriate socio-political actions and to new institutional arrangements that will also guide the development of more environmentally appropriate technical tools that will be needed to correct our present situation.

The outcome of the $21^{\text {st }}$ century will very much depend on how we go about this. Measuring success will be much more related to improved qualitative societal involvement than to greater quantitative technical prowess. And as there is no proven recipe, it won't necessarily be easy, but do we have a choice other than taking on this defining challenge? As has been showed briefly, Université de Moncton's three-phased sustainable design and development project seeks not only to participate and demonstrate but to actively engage in this key process. Therein lays its key innovative characteristic as a project which has the potential to affect the rhythm and sensitivities of a region by opening the door to ecological, aesthetical and technological experiences that can serve as a model in Atlantic Canada and elsewhere in Canada.

\section{References}

[1] Artifices, Art contemporain et pluralisme: nouvelles perspectives, L'Harmattan, Paris, 1999.

[2] Arpin, R., Territoires culturels, Bellarmin, Montréal, 2002.

[3] Babin, R. "La modernisation sociétale comme application progressiste du développement durable", Les enjeux actuels $d u$ développement durable: aspects analytiques et dimensions critiques, (sous la direction de la Chaire UnescoUniversité Laval), Presses Université Laval, Québec, 2004. 25 p. (forthcoming)
[4] Babin, R. "Réappropriation communautaire de la protection de l'environnement en Acadie" dans C. Gendron et J.-G. Vaillancourt (éds.), Développement durable et participation publique : de la contestation écologiste aux défis de gouvernance, Les Presses de l'Université de Montréal, Montréal, 2003, pp. 265-285.

[5] Beck, U., The Reinvention of the Political, Polity Books, London, 1995.

[6] Beck, U., The Reinvention of Politics. Rethinking Modernity in the Global Social Order, Polity Press, London, 1997.

[7] Bourg, D., Les sentiments de nature, La Découverte, Paris, 1993.

[8] Collectif, Groupes, mouvements, tendances de l'Art contemporain depuis 1945, École nationale supérieure des Beaux-Arts, Paris, 1990.

[9] Collection « reConnaître ». herman de vries les choses mêmes, Réunion des musées nationaux, Paris, 2001.

[10] Cunningham, S. The Restoration Economy. The Greatest New Growth Frontier, Berrtt-Koehler Publishers, San Francisco, 2002.

[11] Duclos, D., De la civilité. Comment les sociétés apprivoisent la puissance, La Découverte, Paris, 1993.

[12] Duclos D., Nature et démocratie des passions, PUFSociologie d'aujourd'hui, Paris, 1996.

[13] Durand, Guy Sioui, L'art comme alternative. Réseaux et pratiques d'art parallèle au Québec, 1976-1996, Éditions Intervention, Québec, 1997.

[14] Duvighaud, J., Sociologie de l'art, Presses Universitaires de France, Paris, 1967.

[15] Fisher, H. Théorie de l'art sociologique, Casterman, Paris, 1977.

[16] Florida, R., "The Rise of the Creative Class", The Washington Monthly, Online, May 2002, 14 p.

[17] Forest, F., Repenser l'art et son enseignement. Les écoles de la vie, L'Harmattan, Paris, 2002.

[18] Garaud, C., L'idée de nature dans l'art contemporain, Flammarion, Paris, 1993.

[19] Giddens, A., La constitution de la société. Éléments de la théorie de la structuration, PUF, Paris, 1987.

[20] Goldsworthy, A., A Collaboration with Nature, Harry

N. Abrams, Inc. Publishers, New York, 1990. 
[21] Grande, J. K., Intertwining. Landscape, Technology, Issues, Artists, Black Rose Books, Montréal, 1998.

[22] Grande, J. K., Art, nature et société, Éditions Écosociété, Montréal, 1997.

[23] Guérin, J-L., Jardin d'alliances pour le XXI siècle, L'Harmattan, Paris, 2002.

[24] Kepes, G. (ed.), Arts of the Environment, George Braziller, New York, 1972.

[25] Laroche, H., D. Lonergan, and A.-M. Richard (éds.), Symposium d'art actuel 1999 «Attention le Mascaret ne siffle pas », Association acadienne des artistes professionnel.le.s du Nouveau-Brunswick, Moncton, 2001.

[26] Lucie-Smith, E., Les mouvements artistiques depuis 1945, Éditions Thames \& Hudson, Paris, 1999.

[27] MACM - Musée d'art contemporain de Montréal, Art et jardins. Nature/Culture, MACM, Montréal, 2000.

[28] Morin, E., Les sept savoirs nécessaires à l'éducation du futur, Unesco, Paris, 1999. Internet: http://www.agora21.org/unesco/7savoirs/7savoirs03.html

[29] Nils-Udo, Towards Nature, Kyodo News, Tokyo, 2002.

[30] Nils-Udo, Nils-Udo, l'art dans la nature, Flammarion, Paris, 2003.
[31] Penders, A-F., En chemin, le Land Art, Éditions de la Lettre volée, Bruxelles, 1999, Tome 1 : Partir, 256 p. ; Tome 2 : Revenir, $104 \mathrm{p}$.

[32] Perret, and E. Caillet (eds.), L'art contemporain et son exposition (1), L'Harmattan, Paris, 2002.

[33] Plumwood, V., Environmental Culture. The Ecological Crisis of Reason, Routledge, London/New York, 2002.

[34] Salomon, J-J., Survivre à la science. Une certaine idée du futur, Fayard, Paris, 1999.

[35] Schwenk, T., Le chaos sensible. Création de formes par les mouvements de l'eau et de l'air, Éditions du centre Triades, Paris, 1982.

[36] Semin, D., L'arte povera, Édition du Centre George Pompidou, Paris, 1992.

[37] Thompson, D'Arcy, On Growth and Form, Cambridge University Press, Cambridge (UK), 1992.

[38] Tiberghien, G. A., Nature, Art, Paysage, Actes $\mathrm{Sud} /$ École nationale supérieure du paysage, Arles (France), 2001.

[39] Touraine, A. Pourrons-nous vivre ensemble? Égaux et différents, Fayard, Paris, 1997. 